\title{
The Social Function Of Land In Liberal And Islamic Law Perspective
}

\author{
Nur Adhim', Sukirno², Muh. Afif Mahfud ${ }^{3}$ \\ \{nuradhimundip@gmail.com ${ }^{1}$, kirnoundip@yahoo.com ${ }^{2}$, cicihhilali@yahoo.com ${ }^{3}$ \} \\ ${ }^{1,2}$ Law Faculty, Diponegoro University, Semarang, Jawa Tengah 50275, Indonesia \\ ${ }^{3}$ Law Science Doctoral Program, Diponegoro University, Semarang, Jawa Tengah 50275, \\ Indonesia
}

\begin{abstract}
Land has vital role in human life to be utilized and used for their viability. Land use and utilization must consider its social function. The purpose of this research to describe philosophy of land ownership in liberalism and Islamic law perspective. This research uses conceptual and comparative approach. This research uses secondary data. Collected data is analyzed based on interactive model as stated by Matthew B. Miles and Michael C. Hubberman. This research shows that philosophy of land social function in liberalism perspective put emphasize the importance of individual ownership and his freedom in using and utilizing it without considering its social impact. In this perspective, land ownership is purpose and meaning of life. It is different from Islamic law perspective which allow individual need but its use is limited by social, morality and spiritual aspect (liability to God Almighty)
\end{abstract}

Keywords: Social Function, Liberalism, Islamic Law

\section{Introduction}

Land has very vital role in human life from economic, social, cultural and religion aspect. Related to the importance of land and complex problem related to the land which arise because of less land parcel if this is compared with the number of man in need. Based on such understanding, it is important to make regulation about land ownership. In this circumstance, regulation on land parcel is tightly related with religion teaching and ideology which base its making. In this world, one of the prominent ideology and used in many countries is liberalism ideology which emphasize on individual freedom. This ideology arises as reaction of limitation individual expression mainly in economic and politic which then influence the entire aspect of human life. In liberal ideology, person is the main focus and separated from its society.

In another side, there is also regulation on religion teaching about ownership include land. One of the religion which regulate that is Islamic religion. Different from liberalism ideology which emphasize on individual freedom, Islamic religion teaching stress on society as unity of person and it can not be separated from his position as part of society. So that, there is very strong regulation between both of those things. 
The difference of perspective between liberalism ideology and Islamic teaching in considering individual position in society influence its policy include social function of land ownership. Social function of land is firstly expressed by Auguste Comte in 1850 and then developed by France academician named Leon Duguit. In his opinion, the government must ensure that land use must consider and pay attention other people interest or social function. This is then adopted in many countries and be one article of constitution such as Brazil and there is also state which regulate social function in Law such as in Indonesia namely Article 6 of Law No. 5 Year 1960 on Basic Regulation of Agrarian.

The social function of land is interesting to be analyzed in its relation to liberalism ideology and Islamic religion teaching. It is interesting to be analyzed in relation to liberalism ideology and Islamic teaching. Based on that explanation, it urges writer in making article on title the social function of land in liberal and Islamic law perspective.

\section{Methodology}

This research is based on qualitative research tradition with conceptual and comparative approach. This research uses secondary data. Collected data is then analyzed by using interactive model as stated by Matthew B. Miles and Michael C Hubberman. Data analysis based on that model is begun by data reduction, data show and conclusion making.

\section{Discussion}

In Islamic religion teaching, land is considered as valuable thing from economic, social, politic and spiritual perspective. In Islamic religion teaching, land ownership is theocentric or instrument in praying to God Almighty. This is based on understanding that land is truly ALLAH SWT (God) ownership. In Islamic cosmology, everything is created by god and devoted to praying him. Farooq Aziz and Naveed Ur Rehman Khan state that land ownership or land title is widening of home ownership interpretation because in Islam, land and building ownership is in unity [1].

Land in Islamic religion teaching can be divided into three, namely [2] : first, individual ownership which is ownership of a person to the land and all attached things on that object. It means in Islam, the principle used is attachment principle. Secondly, communal ownership or joint ownership namely ownership ownership of a parcel jointly by several people or groups. Thirdly, communal ownership namely joint ownership by all the people in one community or society.

Based on explanation above, a person can be given land title with considering social function of land especially redistribution aspect. The purpose of admittance of individual ownership is to maintain and defend its existence as human and slave of God Almighty ALLAH SWT. This is based on principle that all people have right to get benefit from land created by God. The redistribution aspect shows that social function in every individual ownership.

Individual ownership in Islam is not ownership which stress on individual freedom and without any border. In Islam, individual ownership of land use must not create land concentration of individual ownership to the parties and persons as which prevail in Pre 
Islamic time. Based on Ridwan opinion, in pre Islamic time, there is concentration of land ownership in figures or tribe leaders because of conquering to the weaker tribe and grabbing to the people wealth to be owned and used individually and not placed as communal property of that community [3].

This condition is contrast with Islamic religion teaching which forbid concentrated land ownership and taken in bad way. Islamic teaching also considers natural resources include land so that there is prosperity for all person and distributed land must be used productively. This land also is forbidden to exploited in over rate. Both those things are related to social function of land namely distribution of land ownership to main together prosperity and this is implemented through baitul maal as institution whose duty in fulfilling people need especially for the landless [4]. Land productivity will be achieved through obligation for every land owners to actively use its land. The purpose of this policy is to prevent idle land [5].

Individual land ownership in Islam means that there is authority to that person in land accessing over his own land and exclude other people from using that land but its use is still under limitation. The limit in land use is not to obstacle or bring detriment others interest and sincerely give the land for general interest when the state need [6]. Based on that regulation, the social function of land in Islamic perspective is interpreted widely and not only related to person to person relationship but also between person and society in general. The social function of land in Islamic concept is much wider than Indonesian law that only regulate social function in relation between person and society and it not regulate about individual or person to person relationships.

The concept of land social function in Islamic teaching is come much earlier than in Western even though in many literatures or articles is always mentioned that the one who puts milestone on social function concept is Leon Duguit in 1919. The social function of land concept Is based on description over social reality which put solidarity as its main base. In Duguit perspective, person is part of the society so that individual land use must pay attention or consider other person and society interest [7]. It shows that person or individual is not an otonom unit which is free from context or society around. Based on that understanding, land ownership and use by a person can not be released from his society. The concept of land social function stated by Duguit at the beginning is a critique to liberal ideology which separate a person from society around.

This liberal ideology at the beginning is tightly related to John Locke, Samuel Pudendorf and France Revolution. Even though those people are mentioned as influential figures in capitalism development but liberalism has existed since Ancient Greek era. The figure of liberal at the time is Alcidamos who state that god create all people in freedom and no one is naturally or born as a slave. So that, human is truly has equal power and freedom [8].

Liberalism can be defined as an ideology with main purpose is to maintain and develop constitutional democracy, individual freedom, fulfillment of human right and civil rights which is important in maintaining human life. Related to this liberalism, there are two monumental documents as basis of liberal ownership namely Rights of Man of 1789 and the Napoleonic Code. In Article 544 and 545 of Napoleon Code is regulated that: Property is the right of enjoying and disposing of things in the most absolute manner, provided they are not used in a way prohibited by the laws or statutes. No one can be compelled to give up his property, except for the public good, and for a just and previous indemnity. 
Based on that article, since at the beginning land title is categorized as absolute right. It means, the owner is given an absolute right to use its land as free as possible without any obligation to pay attention or consider other people interest or social function of that land.

According to John Locke and John Stuart Mill, a person gets land possession based on his work or effort over that land. Man is free to act in his own land without getting permit from whoever include government [9]. Individual freedom in enforcing his right is named as negative liberty. It means that freedom is no obstacle, coercion and intervention from whoever or other parties include government in using his land [10]. One important thing to be stated as characteristic of liberalism is state neutrality, promoting individual freedom and equal attention given to every person.

In liberal ideology, the government must enforce individual right and facilitate its use. The government must not intervene in that individual land use. Adam Przeworski and Fernando Limongi state that government intervention is a kind of threat to individual freedom in land use [11]. It means state must create a good condition in developing liberalism through lessen its role in economic include to land use and ownership.

In liberal ideology, every person is considered as rational being whose capacity to think about consequence of its action. The perspective which put a person in such manner cause every person to deserve on liberty in using his without any limit include another person interest because this person is considered to know about implication from his action and decision.

Based on explanation above, the difference between liberal ideology and Islamic teaching related to land can be seen in table 1:

Table 1. The difference between liberal ideology and Islamic teaching related to land [3]

\begin{tabular}{|c|c|c|}
\hline Aspect & Liberal & Islam \\
\hline Ideology & Liberal-Individualistic & Religious-Communalism \\
\hline Policy Orientation & Individual welfare & $\begin{array}{l}\text { Public welfare based on the principle } \\
\text { of justice (al-adalah) and equality (al- } \\
\text { musawah) }\end{array}$ \\
\hline Strategy & $\begin{array}{l}\text { Individual is free in using its land. } \\
\text { There is no social function }\end{array}$ & $\begin{array}{l}\text { Land ownership structuring through } \\
\text { land reform program (al-iṣlah al- } \\
\text { zira } i^{-} \text {) }\end{array}$ \\
\hline $\begin{array}{l}\text { State } \\
\text { Power/Intervention }\end{array}$ & $\begin{array}{l}\text { State intervention is minimum. State } \\
\text { intervene when there is problem } \\
\text { (passive). }\end{array}$ & $\begin{array}{l}\text { Conducted by the head of the state in } \\
\text { the name of the state (institution) } \\
\text { through the instruments of hima and } \\
\text { iqta' with an orientation different } \\
\text { from what was practiced in the Pre- } \\
\text { Islamic period. }\end{array}$ \\
\hline Principle & $\begin{array}{l}\text { Land for individual who works for his } \\
\text { own wealth. }\end{array}$ & $\begin{array}{l}\text { Land for the welfare of cultivating } \\
\text { farmers or those in service of Islamic } \\
\text { development }\end{array}$ \\
\hline Perspective/Concept & $\begin{array}{l}\text { Land as result of individual effort. It } \\
\text { is only put as capital asset }\end{array}$ & $\begin{array}{l}\text { Land as a trusted entity from Allah } \\
\text { should be managed by the state for } \\
\text { public welfare (maslahah ammah) } \\
\text { through the land reform programs. } \\
\text { Land has theological, economic, } \\
\text { social and political dimensions. }\end{array}$ \\
\hline Social Function & Individual, liberal, free competition. & Social, humanistic and religious \\
\hline
\end{tabular}




\begin{tabular}{|l|l|l|}
\hline & $\mid$ & function of land use \\
\hline Release of Rights & $\begin{array}{l}\text { Right is released through private } \\
\text { transaction between state and } \\
\text { individual }\end{array}$ & $\begin{array}{l}\text { Right release for public interests by } \\
\text { the state is allowed only based on } \\
\text { public benefit along with the } \\
\text { provision appropriate } \\
\text { compensation. }\end{array}$ \\
\hline
\end{tabular}

Based on table 1, there are several very sharp differences between liberal ideology and Islamic teaching. Liberal ideology stress on individual freedom and welfare. In another side, Islamic teaching, oriented to common welfare through recognition for individual ownership. In achieving common welfare there must be natural resources distribution include land. This distribution need leader role. In contrast, liberal ideology lessens state or leader role because land is considered as commodity in which the ownership is based on labor and free competition. It is different from Islam which consider land as social and humanistic object. It is also an instrument in praying to God Almighty.

\section{Conclusions}

Liberal ideology which stress on freedom and put a person as otonom unit and not related to his society make there is no social function of land in this ideology. Land in liberal perspective is a capital asset gotten through labor and free competition. It is different from Islamic teaching which recognize individual ownership and put that person as bounded part of society so that there must be wealth distribution. Land use in Islam is limited by social, morality and spiritual aspect.

\section{References}

[1] N. U. R. Dr. Farooq Aziz, "Refutation of Private Ownership of Land: An Islamic Perspective," Islam. Econ. Bank. Finance., vol. 8, p. 84, 2012.

[2] D. S. M. Niazi, "The Nature of Property, Its Valuation and Intellectual Property Rights in Islamic Law,” J. Islam. Stud. Cult., 2016.

[3] R. Ridwan, "Land Ownership Reform in Islam," Asian Soc. Sci., 2019.

[4] S. Sait and H. Lim, "Land, Law and Islam," Prop. Hum. Rights Muslim, 2006.

[5] Mahmoud A. Gulaid, Land Ownership in Islam (A Survey). 2005.

[6] S. Mariam and M. S. Salasal, "The concept of land ownership: Islamic perspective," Bul. Geoinformasi Jld. 2 No. 2, no. 2, pp. 285-304, 1998.

[7] T. T. Ankersen and T. Ruppert, "Tierra y Libertad: The Social Function Doctrine and Land Reform in Latin America," in Léon Duguit and the Social Obligation Norm of Property, 2019.

[8] A. Gorun, "The idea of freedom and the premises of liberalism in Greek thought," Eur. Res. Stud. J., 2010.

[9] G. Azam, "Classical Liberalism and its Limits," Philos. Prog., 2016.

[10] M. Friedman, The Basic Principles of Liberalism. Presented in a public lecture at Wabash College, 21 June 1956.

[11] A. Przeworski and F. Limongi, "Political regimes and economic growth," Desarro. Econ. Rev. Ciencias Soc., 1994. 